\title{
Medicinal uses and natural availability of three plant species in selected ecosystems in cameroon
}

\begin{abstract}
In many developing countries traditional medicine constitutes a major part of health care because of its local availability and affordability compared to modern medicine. However, little is known about the specific uses and availability of medicinal plants. In this research an exploratory study was conducted to determine the uses of three medicinal plants in Cameroon, and to examine their relative distribution and abundance in specific habitats. From a questionnaire administered to traditional healers, we found that three species of medicinal plants including: Alstoniaboonei, Picralima nitida and Sarcocephaluslatifolius that are commonly used, either singly or in mixtures to treat human diseases such as muscle and joints pains, hyperthermia, hypertension, hepatitis, jaundice and rheumatism. Fresh or dry barks of the tree plants and fresh fruits of Picralima nitida, as well as various ethnopharmacological preparations (decoctions, maceration, infusion and powder) are widely commercialized. Findings from our ecological study revealed that Alstoniaboonei was represented by 2 , or $1 \%$ of total individuals recorded in 0.5 ha, implying 3 individuals and 6 trees/ha This tree was well represented and was sometime among the dominant species in the forests. Picralima nitida was represented by $0.6 \%$ of total trees recorded in 0.5 ha, implying 0.70 tree and 1 tree/ha. This tree was poorly represented and was not a dominant species in its habitats. Sarcocephaluslatifolius belonged to a group of 72 plants with a recovery $<5 \%$ corresponding to Braun- Blanquet scale 1 . Hence, this plant was not densely represented in the Sudano-Guinean and Sahelian savannahs. It is the most harvested species of the three species that has undergone a strong anthropogenic destruction. Therefore these three plants, and especially Sarcocephaluslatifolius, need to be protected through a sustainable management of their habitats in Cameroon.
\end{abstract}

Keywords: natural availability; alstoniaboonei; picralima nitida; sarcocephaluslatifolius; monospecific and polyspecific recipes; disease control; irrational exploitation; conservation strategies
Volume 4 Issue 4 - 2017

TsabangNolé,Atsamo Albert, Donfagsiteli N, Yedjou Clement G,TchindaThiabo Alembert, Agbor Gabriel A,Tchounwou Paul Bernard, Tsambang Joel Elysée Tsafack

IInstitute of Medical Research and Studies of Medicinal

Plants, Cameroon

'University of Yaounde, Department of Animal

Biology, Cameroon

${ }^{3}$ High Institution of Environmental Science, Cameroon ${ }^{4}$ Cellomics and Toxicogenomics Research Laboratory, JacksonState University, USA

5Jackson State University, USA

Correspondence: Tsabang Nolé,Center for Research on Medicinal Plants and Traditional Medicine, Institute of Medical Research and Studies of Medicinal plants, Ministry of Scientific Research and Innovation, High Institution of Environmental Science, Cameroon, Email tsabang200I@yahoo.fr

Received: March 10, 2017 | Published: April 13, 2017

\section{Introduction}

An ethnobotanical survey, realized in Cameroon from 2003 and 2015 has permitted to identify three medicinal plants with traditional monospecific and multispecific uses. These plants are constituted of two Apocynaceae Alstoniaboonei and Picralima nitida and one Rubiaceae Sarcocephalus latifolius Syn. Nauclea latifolia. The two Apocynaceae are forests species while Sarcocephalus latifolius grows in Guinean, Sudanian and Sahalian savannahs. The increasing harvest of these plants for their medicinal uses has reduced their population densities in their-natural ecosystems. This situation is more frequently observed near strong agglomerations especially in the Northern regions of Cameroon, where various formulations of Sarcocephalus latifolius are currently used to treat diverse human diseases. Climate change is another important factor that can affect their perennity. The discovery in natural state of the synthetic Tramadol, a sedative molecule from this African plant has increased its medicinal uses by local people. ${ }^{2-4}$ The combination of its barks with those of Picralima nitida and of Alstoniaboonei by traditional healers has contributed to an increasing in the exploitation of these natural resources. Therefore the present scientific research has provided new insights on the overexploitation of Sarcocephaluslatifolius and related plants, for medicinal purposes. The main diseases treated by these three species of plant are: muscle and joints pains, hyperthermia, hypertension, hepatitis, jaundice and rheumatism. The more rich in documented information of the three species are Alstonia boonei and Sarcocephalius latifolius.${ }^{1,2}$ Crude extracts of these plants, either alone or in combination of two or three mixtures, are sold by travelling healers or hawkers in Cameroon's markets. In the present study our first objective was to document the medicinal uses of these natural plants and the second was to evaluate their relative dominance and abundance in order to establish their availability and population densities in their natural habitats.

\section{Materials and methods}

A survey questionnaire was designed, validated and administered to residents of the study areas. Data were collected from 1131 respondents drawn from 58 tribes. The distribution of the respondents included 70 traditional healers and 1,061 other resource persons. ${ }^{5}$ The process used to collect information began by a fieldwork focusing on harvest and identification of the three plants. During this step ethno pharmacologicaldetails on the preparation of recipes were described with the help of informants. This description focused on the mode and the time of preparation, the mode of administration, the posology, the duration of treatment, the undesirable or secondary/ toxic effects, and the diseases treated. It was followed by the chemical and pharmacological approach based on investigation of previous searches. hence chemistry and pharmacology have also played a great role in the evaluation of natural products. ${ }^{6}$ Confirmation of botanical identification was done in National Herbarium of Cameroon and voucher specimens are deposited in the Institute of Medical Researches and Medicinal Plants Studies.

For Alstoniaboonei and Picralima nitida which are forest species their abundance and their dominance were assessed in their habitats by a sampling method that was based on the establishment of quadrats 
or parcels of 0.1 ha $(100 \mathrm{~m} \times 10 \mathrm{~m})$ each. The device in Figure 1 was used for this inventory.

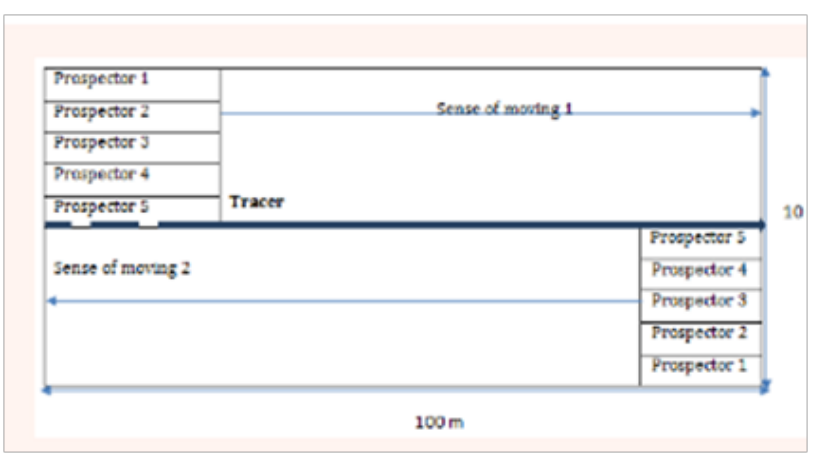

Figure I Improved methods for trees assessing and monitoring.

RD: relative density; RA: relative abundance.

A total of 15 quad rats were established in three habitats: 5 for Alstoniaboonei in the Littoral and continental humid rain forests zone of transition, 5 also for Alstoniaboonei in the Banana's plantations in Littoral humid rain forests and 5 for Picralima nitida in the Littoral and continental humid rain forests zone of transition. In these specific habitats each plant is highly harvested for supplying towns' markets with medicinal products. A total surface of 1 ha was covered. The following formulas were used to calculate abundance and dominance of these two recorded trees species with circumference at the breast high $(\mathrm{CDH})>32 \mathrm{~cm}$ in each habitat. ${ }^{7,8}$

\section{Basal surface}

$S b=\pi X(D / 2)^{2}$ with $\mathrm{Sb}=$ surface basal and $\mathrm{D}=$ diameter. For a given family or species it corresponds to the sum of basal surface of different individuals of this family or species. Abundance of taxa: $\mathrm{AT}=($ number of individuals of a species or of a family)x $100 /$ total number of recorded individuals. Dominance of taxa: DT $=($ basal surface of a species or a family)x $100 /$ total basal surface of all recorded individuals.

For Sarcocephaluslatifolius, shrub of savannahs, the floristic diversity was evaluated following a sampling based on the establishment of quadrats of 1 ha $(100 \mathrm{mx} 100 \mathrm{~m})$. A total of 5 quadrats were sampled. A total surface of 5 ha was recovered. The method founded on the notion of the characteristic species ${ }^{9}$ was used to study the vegetal community living in the quadrats or the parcels. The list of all the species encountered in the 5 quadrats was established with their abundance-dominance that is an expression of the relative space occupied by the set of individuals of each species space which is at once determined by their number and by their dimension. The usual scale for the evaluation is that of Braun-Blanquet ${ }^{9}$ described in Table $^{-}$ 1 below.

$C S i=F \operatorname{Sin} \sum i=1 F S n$ Specific frequencies SiF, and centesimal frequencies $(\mathrm{CF})$ derived from these data have permitted to obtain an expression of recovery for each species at level of soil. ${ }^{11,12}$ It is equal to proportion (expressed in \%) of number of repetitions of the given species divided by a total number of quadrats sampled. The " specific contribution» $\mathrm{SiC}$, which is defined as the rate of the specific frequency $\mathrm{SiF}$ and the sum of the specific frequencies of all the species recorded, was calculated according to the following formula:

Where $\mathrm{SiC}$ and $\mathrm{SiF}$ are the contribution and the specific frequency of the species $i$ and $n$ the total number of species.

\section{Ecological statistical analysis}

Diversity assessment was done using Shannon-Weiner and Evenness. Shannon index (H).

$H=-\sum p i$ In pi measures the incertitude link to the appearance of an individual of a given species taken at random in the sample.

Where pi is the proportion of individuals of a species i (Relative density of species), and In is the natural logarithm. The maximum value of $\mathrm{H}^{\prime}$ is the natural logarithm of the number of species $(\operatorname{In} \mathrm{S})$.

Evenness

(Evenness (E) $E=H / \operatorname{InS}$ describes the distribution among species, reaching a value of 1 when all species have equal numbers of individuals.

\section{Results}

\section{Different uses of the three species}

The combined and single medicinal and non-medical uses of the three plants by local people are presented in Table 2 .

\section{Presentation of ecological study of the three plant species}

\section{Dominance and abundance}

\section{Alstoniaboonei}

Specific composition of the five quadrats located in Littoral and continental humid rain forests zone of transition: In this feature of vegetation, 125 individual trees were recorded. They belong to 24 families, 51 genera and 66 species. Alstoniaboonei was represented by $2.1 \%$ of total individuals recorded in $0.5 \mathrm{ha}$, implying 2.625 individuals and 6 trees/ha (Figure 2). This species was least abundant and dominant. The timbers' exploitation repulses this tree towards the versants of mountains difficult to reach. So like others species, the enclosure is favorable for it conservation.

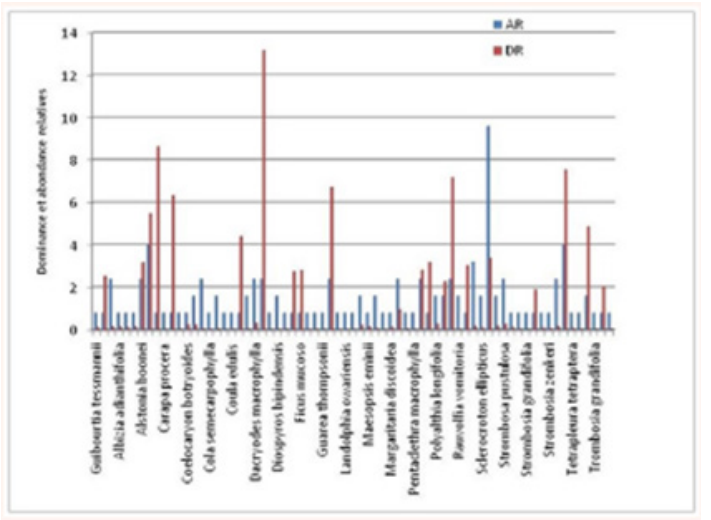

Figure 2 Abundance and dominance of species in Alstonia boonei forest habitats.

Specific composition of the five quadrats located in the banana's plantations: This feature of vegetation had 109 recorded trees. These trees belonged to 21 families, 31 genera and 35 species. Alstoniaboonei was represented by $2 \%$ of total individuals recorded in 0.5 ha, implying 2.5 individuals and 5 trees/ha (Figure 3 ). This feature is nearly the same in the forest. Banana's farming is a moderate means of useful trees conservation. 


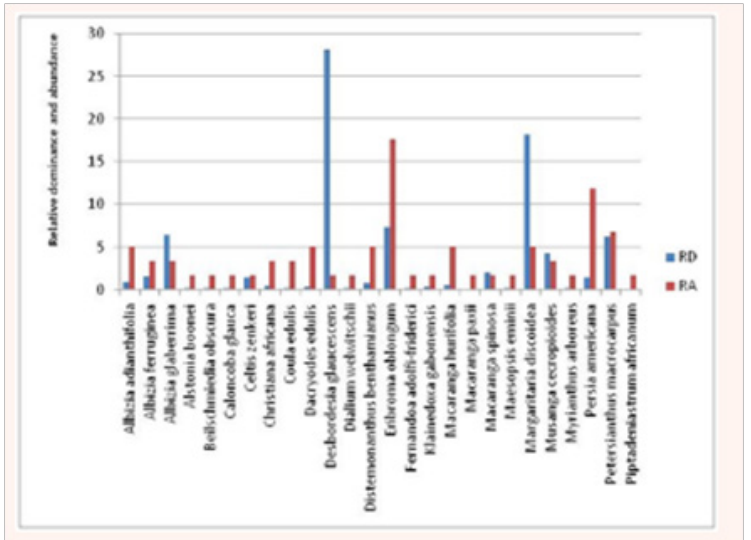

Figure 3 Abundance and dominance of species in Alstonia boonei banana's plantations habitats.

RD: relative density; RA: relative abundance.

\section{Picralima nitida}

Specific composition of the five quadrats in continental humid dense old secondary forests: A total of 164 trees were recorded in five quadrats of 0,1 ha, implying 328 trees/ha. They belonged to 23 families, 42 genera and 47 species. Picralima nitida was represented by $0.6 \%$ of total individuals recorded in $0.5 \mathrm{ha}$, implying 0.70 individual and 1 tree/ha. This species is the least abundant and least dominant (Figure 4). Picralima nitida is an understory tree of rainforests, which is also found in semi-deciduous forests on the banks of rivers, up to 900 m altitude in Cameroon.

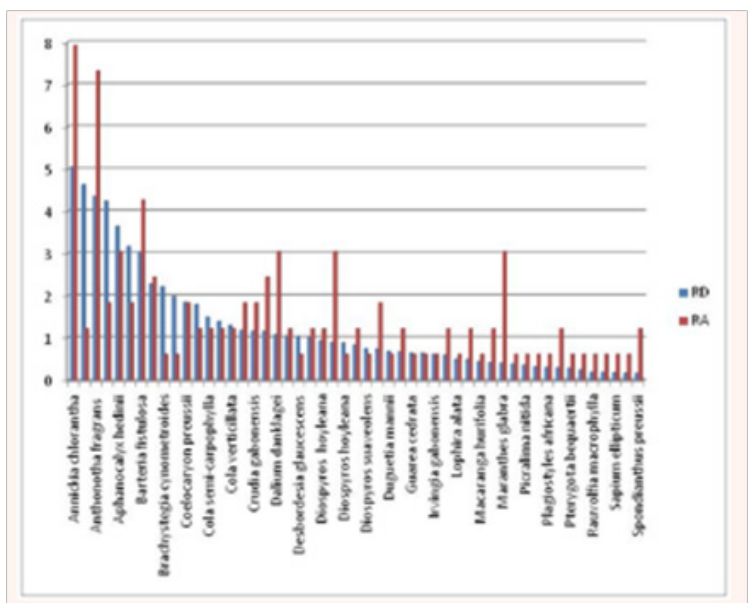

Figure 4 Abundance and dominance of Picralima nitida species in continental forests habitats.

RD: relative density; RA: relative abundance.

\section{Sarcocephaluslatifolius}

The Figure 4 shows that Sarcocephaluslatifoliuswhich belonged to a group of 57 plants with a recovery $<5 \%$ corresponding to BraunBlanquet scale 1 (Figure 5) was weakly represented in its Adamawa region's savannahs.

\section{Statistical analysis of results}

The different indices of biodiversity are presented in Table 2 .

Different levels of disturbance have effects on plant diversity mostly. Parcels were located in four main characteristic types of vegetation (Table 2).

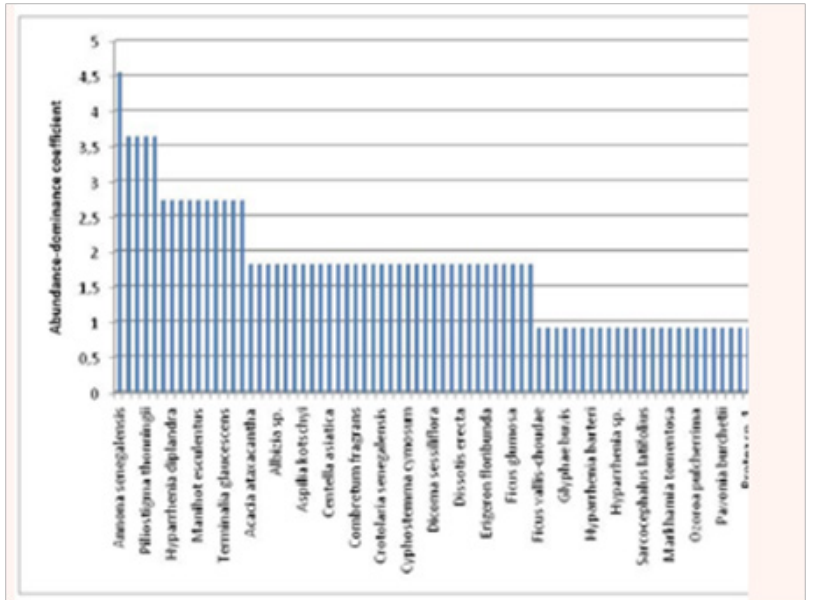

Figure 5 Abundance-dominance coefficient of species in Sarcocephalus latifolius savannahs habitats.

\section{Banana's Farms in littoral humid rain forests}

The numbers in brackets correspond to Shannon's index of species. The common characteristic of these habitats is the presence of young pioneer species that include Macaranga hurifolia (0,25), Macaranga spinosa (0,25), Macaranga paxii $(0,16), \quad$ Albizia adanthifolia $(0,23)$, Albizia ferruginea $(0,20)$, Albiziaglaberrima $(0,20)$ and Tremaorientalis $(0,20)$. Cultivated species was represented by Persea americana the more frequent plant $(0,27)$. Among the plants conserved for their medical uses were Musanga cecropioides $(0,20)$, Petersianthus macrocarpus $(0,20)$, Alstonia boonei $(0,13)$ one of the main useful plant of this study and Strombosiopsis tetrandra $(0,13)$ are found in third position, following by Piptadeniastrum africanum $(0,07)$ and Spathodea campanulata $(0,07)$. Some plants were conserved for their other uses like Beilschmiedia obscura $(0,13)$ which seed are spice. The most important plants kept for protecting banana and cacao are plants for shadow that include Strombosa pustulosa $(0,20)$, Klainedoxa gabonensis $(0,20)$, Distemonanthus benthamianus $(0,07)$ and Dialiumwelwitschii $(0,07)$. This last category of plants is lumber for local people.

\section{Littoral and continental humid rain forests zone of transition}

The most abundant tree of this site is Staudtia kamerunensis $(0,23)$ and Terminalia superba $(0,23)$. The family of CeasalpIniaceae represented by Afzelia bipindensis (0,13), Afzelia pachyloba $(0,13)$, Berlinia bracteosa $(0,13)$, Erythrophleum suaveolens $(0,13)$ and Guibourtia tessmannii $(0,13)$ is dominant. The Fabaceae with Pterocarpus soyauxii $(0,20)$, Pterocarpus pterocarpoides $(0,07)$ is very representative like Mimosaceae as Pentaclethra macrophylla $(0,16)$, Piptadenistrum africanum $(0,13)$, Tetrapleura tetraptera $(0,13)$ and Cylicodiscus gabunense $(0,12)$. Other large canopy trees include Pycnanthnus angolensis $(0,20)$, Petersianthus macrocarpus (0,20), Alstoniaboonei $(0,16)$, Ceiba

pentandra $\quad(0,16), \quad$ Cleistopholis patens $(0,16), \quad$ Sterculia tragacantha $(0,16)$, Maranthes glabra $(0,13)$, Margaritariadiscoidea $(0,13)$, Ricinodendron heudelotii $(0,13), \quad$ Santiria trimera $(0,13), \quad$ Strombosia grandifolia $(0,13), \quad$ Tridesmostemon 
omphalocarpoides $(0,07)$, Sacoglottis gabonensis $(0,13)$ and Uapaca guineensis $(0,13)$. To the lesser extent, other trees as Cola verticillata $(0,07)$, Coula edulis $(0,07)$, Lophiaalata $(0,07)$, Dacryodes macrophylla (0,07), Ficus mucoso $(0,07), \quad$ Garcinia mannii (0,07), Guarea thompsonii $(0,07), \quad$ Macaranga hurifolia $(0,07)$, Maesopsis eminii $(0,07)$ and Polyalthia suaveolens $(0,07)$ are also represented.

\section{Continental humid rain forests}

Large trees which dominated the canopy are Vitex cienkowskii (0,12), Tabernaemontana crassa $(0,12)$, Lovoa trichyloides $(0,12)$, Irvingia gabonensis $(0,12)$, Hylodendron gabunense $(0,12)$, Funtumia elastica $(0,12)$ and Amphimas pterocarpoides $(0,12)$. Other trees of canopy less representative are: Afzelia pachyloba $(0,07)$, Alstonia boonei (0,07), Amphimax ferrugineus $(0,07)$, Annickia chlorantha $(0,07)$, Antiaris welwitschii $(0,07)$, Beilschmiedia letouzeyi $(0,07)$, Cleistopholus patens $(0,07)$, Coelocaryon preussii $(0,07)$, Cola semi-carpophylla $(0,07)$, Dacryodes macrophylla $(0,07)$, Desbordesia glaucescens $(0,07)$, Diospyros bipindensis $(0,07)$, Distemonanthus benthamianus $(0,07)$, Maranthes gabunensis $(0,07)$, Musanga cecropioides $(0,07), \quad$ Picralima nitida $(0,07)$, Piptadeniastrum africanum $(0,07)$, Pterygota bequaertii (0,07), Pycnanthus angolensis $(0,07)$, Santiria trimera $(0,07), \quad$ Spondianthus preussii $(0,07), \quad$ Staudtia kamerunensis $(0,07)$, Strombosia grandifolia $(0,07)$, Terminalia superba $(0,07)$, Treculia africana $(0,07)$, Uapacaguineensis $(0,07)$, $(0,07)$, Xylopia hypolampra $(0,07)$ and Zanthoxylum heitzii $(0,07)$.

Sudano-Zambesian Savannahs of Adamawa. The most numerous species of this site are Terminalia laxiflora $(0,12)$, Asparagus warneckei $(0,12)$, Capparis corymbosa $(0,12)$, Conyza aegyptica $(0,12)$, Diodiascandens $(0,12)$ and Eclipta prostrate $(0,12)$. All other species that include Sarcocephaluslatifolius with 0,07 as Shannon's index, are less representative.

\section{Interpretations}

Table 3 revealed that in the less disturbed littoral rain forests zone of transition the diversity $(5,51)$ and evenness $(0,96)$ were high than in the disturbed Banana's plantations in littoral humid rain forests $(5,15)$ and $(0,99)$. It was more less high in disturbed continental humid rain forests $(4,11)$ ). In the Sudano-Zambesian Savannahs of Adamawa the diversity and the evenness are respectfully 5,06 and 0,99. The individuals in these communities are distributed more equitably among these species. The specific density is high in the forest of transition zone (66), following by 48 in the Continental humid rain forests and 35 in banana's plantations of littoral humid rain forests. La density specific is 57 species in the site of Adamawa's savannahs because herbs were took in account. In the banana's plantations there are 35 species that result from the selective conservation.

Table I Scale of species recovery of Braun-Blanquet

\begin{tabular}{ll}
\hline Percentage of Recovery & Attributed Index \\
\hline Species just present & + \\
Recovery< $5 \%$ & $\mathrm{I}$ \\
Recovery comprised between $5-25 \%$ & 2 \\
Recovery comprised between $25-50 \%$ & 3 \\
Recovery comprised between $50-75 \%$ & 4 \\
Recovery $>75 \%$ & 5 \\
\hline
\end{tabular}

Table 2 Combined and single uses of the three plants in Cameroon

\begin{tabular}{llll}
\hline $\begin{array}{l}\text { Species } \\
\text { medical uses }\end{array}$ & Vernacular names & uses & Detailed description of recipes \\
\hline $\begin{array}{l}\text { Alstonia boonei and Picralima } \\
\text { nitida }\end{array}$ & $\begin{array}{l}\text { Ewondo, Boulou, Fang: } \\
\text { Ekuk Ewondo:Abam }\end{array}$ & $\begin{array}{l}\text { Muscle pains, } \\
\text { hypertension }\end{array}$ & $\begin{array}{l}\text { Boil I kg of bark of each plant in } 7 \text { liters of water. Drink } \\
250 \mathrm{ml} \text { of decoction, } 2 \text { times daily to treat hypertension } \\
\text { and use } 5 \text { liters in vapor bath and in bath to treat } \\
\text { rheumatism. }\end{array}$
\end{tabular}

Alstonia booneiand Sarcocephalus Kaka: Lombo Muscle and joints latifolius

Alstonia boonies, Picralima Bakouedje: Fufuldé, nitida and Sarcocephalus latifolius bokoriyi, Gamoyi, Zadeyi Muscle and joints pains, rheumatism.

The decoction of I $\mathrm{kg}$ of bark of each plant or the macerate in 5 liters of water is used in vapor bath and in bath to treat rheumatism. pains, hypertension, jaundice, hepatitis.
Boil I $\mathrm{kg}$ of bark of each plant in 10 liters of water. Drink $250 \mathrm{ml} 2$ times daily to treat hypertension; 250 $\mathrm{ml} 3$ times daily to treat jaundice and hepatitis. Use 5 liters in vapor bath and in bath to treat muscle and join pains. 
Table Continued..

\begin{tabular}{|c|c|c|c|}
\hline \multirow[t]{10}{*}{ Species } & Vernacular names & uses & Detailed description of recipes \\
\hline & Akwaya: Ekuk & Intestinal helmintiasis & $\begin{array}{l}\text { I-Decoction of } 250 \mathrm{~g} \text { of stem bark in } 2 \text { liters. Drink a } \\
\text { half glass thrice a day. }\end{array}$ \\
\hline & Baya: Gouga & $\begin{array}{l}\text { Malaria and repeated } \\
\text { convulsions }\end{array}$ & \multirow{3}{*}{$\begin{array}{l}\text { 2- Soak I kg of stem bark in } 3 \text { liters of water. Stir it from } \\
\text { time to time until it is hot. Drink } 250 \mathrm{ml} \text { of extract. } \\
\text { In cases of strong crisis the patient is taking under } \\
\text { an Alstonia boonei tree and let him take some latex. }\end{array}$} \\
\hline & Bassa: Kotmot & Strangulated hernia & \\
\hline & Bulu, Ewondo, Fang: Ekuk & Expulsion of placenta & \\
\hline & & Rheumatism & $\begin{array}{l}\text { The decoction or the macerate is used in vapor bath } \\
\text { and in bath to treat rheumatism }\end{array}$ \\
\hline & & Malaria & $\begin{array}{l}\text { Macerate } 200 \mathrm{~g} \text { of the inner back in Iliter of water for } \\
\text { about } 2 \text { hours. Drink } 250 \mathrm{ml} \text { daily for a week. }\end{array}$ \\
\hline & Kaka: Lombo & Asthenia & $\begin{array}{l}\text { Mix } 10 \mathrm{~g} \text { of a powdered back in } 20 \mathrm{ml} \text { of hot water. } \\
\text { Drink the macerate, } 2 \text { times daily for a week. }\end{array}$ \\
\hline & & $\begin{array}{l}\text { Cleaning of pus in } \\
\text { wound and opened } \\
\text { fracture }\end{array}$ & $\begin{array}{l}\text { Soak I kg of stem bark in } 3 \text { liters of water. Stir it from } \\
\text { time to time until it is hot. Use the extract to clean pus } \\
\text { in wound and opened fracture. }\end{array}$ \\
\hline & & Antipyretic & \\
\hline \multirow[t]{13}{*}{ Alstonia boonei (Apocynaceae) } & Eton :Akuk & Gonorrhea & $\begin{array}{l}\text { Infusion of } 300 \mathrm{~g} \text { of stem bark in } 2 \text { liters of water. Drink } \\
250 \mathrm{ml} 3 \text { times daily. }\end{array}$ \\
\hline & ELOII. ARUK & Agalactocia & \\
\hline & & Snakebite & Wound the stem and apply the latex on and around the \\
\hline & & Abscess & site of the bite or infection, three times \\
\hline & & Children dermatitis & Stroking or touching on inflamed or eruptive parts. \\
\hline & Bamileke: Ndo Mabeumo & $\begin{array}{l}\text { Genital and urinary } \\
\text { system affections }\end{array}$ & $\begin{array}{l}\text { I- Mix the latex with sugar cane or pineapple juice or } \\
\text { palm oil. Give to drink the mixture to patients. }\end{array}$ \\
\hline & & $\begin{array}{l}\text { Gastro-intestinal } \\
\text { affections }\end{array}$ & $\begin{array}{l}\text { 2- To complete the treatment, purge the patients with } \\
\text { I } 25 \mathrm{ml} \text { of mixture or give to them a urethral or a } \\
\text { vaginal injection or seat bath. }\end{array}$ \\
\hline & & Edema & Apply the pounded leaves in affected parts. \\
\hline & & Antidote & Drink the latex. \\
\hline & & Rheumatism & $\begin{array}{l}\text { Apply the pounded leaves, stem or root barks in } \\
\text { affected parts. }\end{array}$ \\
\hline & & Active purgative & $\begin{array}{l}\text { Take } 10 \text { to } 30 \mathrm{ml} \text { a mixture of Asltonia } \\
\text { boonei and Antostemon aubryanum latex one time }\end{array}$ \\
\hline & Maka: Bamborutuk & & $\begin{array}{l}\text { Decoction of } 250 \mathrm{~g} \text { of stem bark in } 2 \text { liters. Drink a half } \\
\text { glass thrice a day for a week. }\end{array}$ \\
\hline & & Malaria & $\begin{array}{l}\text { Decoction of } 250 \mathrm{~g} \text { of seeds in } 2 \text { liters. Drink a half glass } \\
\text { thrice a day. }\end{array}$ \\
\hline \multirow[t]{6}{*}{ Picralima nitida(Apocynaceae) } & & & $\begin{array}{l}\text { Decoction of } 500 \mathrm{~g} \text { of fruit in } 2 \text { liters. Drink a half glass } \\
\text { thrice a day. }\end{array}$ \\
\hline & & Male sexual impotence & $\begin{array}{l}\text { Maceration of } 300 \mathrm{~g} \text { of bark in } 2 \text { liters. Drink } 250 \mathrm{ml} 3 \\
\text { times daily for a week }\end{array}$ \\
\hline & Baka Pygmies: Mototoko & Dysmenorrhea & $\begin{array}{l}\text { Crush and boil } 300 \mathrm{~g} \text { of fruit. Drink half a glass thrice a } \\
\text { day for three days to a week }\end{array}$ \\
\hline & Bafia: Keledeng & Jaundice, & \\
\hline & $\begin{array}{l}\text { Fufulde: Bakouedje, } \\
\text { Bokoriyi, Gamoyi }\end{array}$ & Yellow Fever & Pound $100 \mathrm{~g}$ of root bark and boil with a half-liter of \\
\hline & Sanaga: Edindingue & Rheumatism & water. Leave to cool before drinking $250 \mathrm{ml}$ two times \\
\hline \multirow{6}{*}{$\begin{array}{l}\text { Sarcocephalus } \\
\text { latifoliusSyn. Nauclea } \\
\text { latifolia (Rubiaceae) }\end{array}$} & & Fever or antipyretic & daily. \\
\hline & & Abdominal pain & \\
\hline & & Hepatitis & \\
\hline & & Jaundice & \multirow{3}{*}{$\begin{array}{l}\text { Pound } 100 \mathrm{~g} \text { of stem bark and macerate in a half-liter of } \\
\text { water. Leave to cool before drinking } 250 \mathrm{ml} \text { of extract } 2 \\
\text { times daily. }\end{array}$} \\
\hline & & Weakness & \\
\hline & Oku : Shi Nkan She & Hepatitis & \\
\hline
\end{tabular}


Table Continued...

\begin{tabular}{|c|c|c|c|}
\hline Species & Vernacular names & uses & Detailed description of recipes \\
\hline \multicolumn{4}{|l|}{ Non-Medical Uses } \\
\hline \multirow{2}{*}{$\begin{array}{l}\text { Sarcocephalus } \\
\text { latifoliusSyn. Nauclea } \\
\text { latifolia (Rubiaceae) }\end{array}$} & & Edible or eatable & $\begin{array}{l}\text { Sweet fruits edible by men and wild animals including } \\
\text { buffalo, monkeys and antelopes. }\end{array}$ \\
\hline & & Colorings & $\begin{array}{l}\text { Yellow extract of roots is used to color animals' skin } \\
\text { and fibers. }\end{array}$ \\
\hline \multirow[b]{2}{*}{ Alstonia boonies } & Gouga: Baka Pygmes & Arrow-poison & The latex is used to prepare arrow poison \\
\hline & $\begin{array}{l}\text { Emien, ekouk : Forestry. } \\
\text { name Alstonia, } \\
\text { cheesewood, stool wood, } \\
\text { pattern wood: English } \\
\text { name. }\end{array}$ & Cash crops' protection & $\begin{array}{l}\text { Alstonia boonei is a useful shade tree for coffee, tea, } \\
\text { cocoa and banana farms. } \\
\text { Alstonia boonei's bark is commonly sold on local markets } \\
\text { in Yaounde, Douala, Limbe, Kumba, for medicinal uses. In } \\
\text { Yaounde, the price of bark ranges from } 500-2000 \text { FCFA } \\
\text { per kilogram depending of the harvesting locality. }\end{array}$ \\
\hline
\end{tabular}

Table 3 Summary of the floristic data for parcels in different areas of ecological study

\begin{tabular}{|c|c|c|c|c|c|c|c|}
\hline Sites & $\begin{array}{l}\text { Number of } \\
\text { parcels }\end{array}$ & $\begin{array}{l}\text { Number of trees } \\
\text { or herbs per ha }\end{array}$ & $\begin{array}{l}\text { Number of } \\
\text { species }\end{array}$ & $\begin{array}{l}\text { Shannon's } \\
\text { index }(H)\end{array}$ & $\begin{array}{l}\text { Pielou's } \\
\text { evenness (E) }\end{array}$ & $\begin{array}{l}\text { Mean } \\
\text { dbh cm }\end{array}$ & $\begin{array}{l}\text { Total Basal } \\
\text { Area in } \mathrm{cm}^{2}\end{array}$ \\
\hline $\begin{array}{l}\text { Banana's Farms in Littoral } \\
\text { Humid Rain Forests }\end{array}$ & 5 & 92 & 35 & 5,15 & 0,98 & 15,45 & 17239,09 \\
\hline Alstonia boonei & 5 & 5 & & 0,13 & 0,13 & 3,10 & 37,72 \\
\hline $\begin{array}{l}\text { Littoral and continental } \\
\text { humid rain forests zone of } \\
\text { transition }\end{array}$ & 5 & 125 & 66 & 5,50 & 0,99 & 45,23 & 200739,50 \\
\hline Alstonia boonei & 5 & 6 & & 0,16 & $0,0 \mid 4$ & 67,62 & 21536,31 \\
\hline $\begin{array}{l}\text { Continental humid Rain } \\
\text { Forests }\end{array}$ & 5 & 112 & 48 & 4,11 & & 42,84 & 161356,55 \\
\hline Picralima nitida & 5 & 1 & & 0,07 & 0,02 & 11,54 & 104,53 \\
\hline $\begin{array}{l}\text { Sudano-Zambesian Savannahs } \\
\text { (Adamawa) }\end{array}$ & 5 & 71 & 57 & 5,06 & 0,99 & & \\
\hline Sarcocephalus latifolius & 5 & 4 & & 0,12 & 0,02 & & \\
\hline
\end{tabular}

\section{Discussion}

Alstonia boonei bark extract showed promising results for antimicrobial effects against bacterial including Bacillus subtilis. Staphylococcusaureus, Pseudomonasaeruginosa, Escherichia coli, and pathgensfunga like Candida albicans. The minimum inhibitory concentrations essay is capable of verifying that compounds possessed antibacterial activities. These compounds can give reliable indication of concentration of medicine required for the inhibition of microorganisms. A. boonei revealed the presence of important minerals that include calcium, phosphorus, iron, sodium, potassium, and magnesium. Other compounds like alkaloids, tannins, saponins, flavonoids and cardiac glycosides, total phenol, important vitamin, ascorbic acid were also found. A. boonei possesses phytochemicals other than phenolics like mineral elements and vitamin $\mathrm{C}$ that may be the important elements in the medicinal activities of $A$. Boonei. ${ }^{13,14}$ Alston boonei and Picralima nitida were identified as antimalarial herbal medicine in Cameoun by the European Commission and FAO project. ${ }^{15}$ Sarcocephaluslatifolius (formerly Nauclea latifolia) is a small shrub (also known as African fisherman) abundantly distributed throughout sub-Saharan Africa. In traditional medicine, especially in Cameroon, this plant is used in the treatment of various pathologies and symptoms, including epilepsy, malaria, fever and pain. ${ }^{16}$

The weak proportions of Alstoniaboonei and Picralima nitida and the low recovery of Sarcocephaluslatifolius in their respective habitats, reveal that plants may not always be naturally available.

\section{Species status and other ecological characteristics}

Despite the fact that the three plants are weakly represented in their habitats, the research of their conserving status in the red list of UICN reveals that none of them is threatened in the world. But none of them is dominant in its present studied habitat in Cameroon. Their long term exploitation can easily lead to their disappearance. Therefore some conservation strategies need to be implemented to overcome the challenge of overexploitation due to the increase in populations and number of patients who need treatment. ${ }^{17}$ The natural habitats degradation leads to rarity of plants. The 5 plots, established in the Littoral rain forest and 5 others in the continental reveal that rain forest are the main habitats of some commonly useful plants in traditional medicine in tropical Africa. The populations continue to exploit this environment. A preservation of the natural resources by the riparian populations seems necessary to promote sustainable management. ${ }^{18}$ For Picralima nitida, on top of bark, seeds and other parts for commercialization in Cameroon markets and medicinal uses are harvested from wild habitats. Sarcocephaluslatifolius is widely distributed in tropical humid forests, in undergrowths of dry forests and savannas of occidental and central Africa. It can grow at an altitude of 0 to $200 \mathrm{~m}$. It is also widely distributed in the African forests and galleries, especially near rivers and outskirts of the ponds. The optimal climatic conditions of this species are a temperature of 27 degrees and an average rainfall of $2700 \mathrm{~m}$. This species still survive at high temperatures around 35 degrees, but dies at low temperatures around 15 degrees. The root system of this plant is more developed 
in shrubbery and in fallow land with a good permeability. There are three types of stems: arborescent, creeping and acaulescent (without visible stem). The color of the roots varies from while to yellow clear depending on whether the soil is sandy or clayey. ${ }^{19}$

This study confirms that it necessary to protect these tree species because they contribute to the treatment of many communities in Africa through the action of travelling healers or hawkers in African's markets. Their importance has also been the subject of reflection on many works including thesis for the purposes of conservation. ${ }^{19}$

\section{Conservation strategies}

The first one is their substitution by an equivalent resource like Sarcocephalusdidericii for S. latifolius which is a forest tree with an important vegetative morphology.

The second one is the cultivation of each one of these species. However, cultivation may destroy other useful plants and also contribute to environmental degradation. The third one is the use of plant biotechnology to produce callus plants that can synthesize the same chemical constituents like the natural plants. The plant biotechnology strategy is the most important way of perpetuating plants, since it does not create damages to the plants' habitats (Supplementary Figures 1-8).

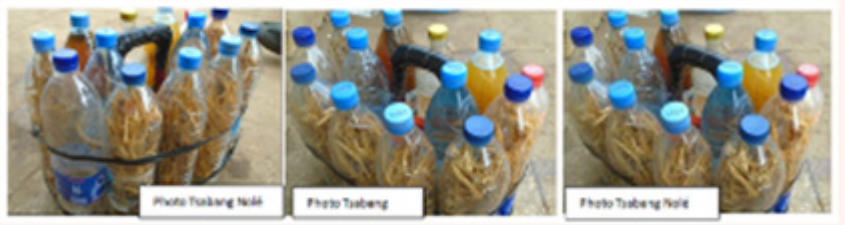

Supplementary Figure I-3 Three lots of different herbal medicines from various mixtures of bark, fresh fruits or root preparations, of Alstonia boonei, Picralima nitida and Sarcocephalus latifolius, sold by three hawkers in Yaounde's markets.

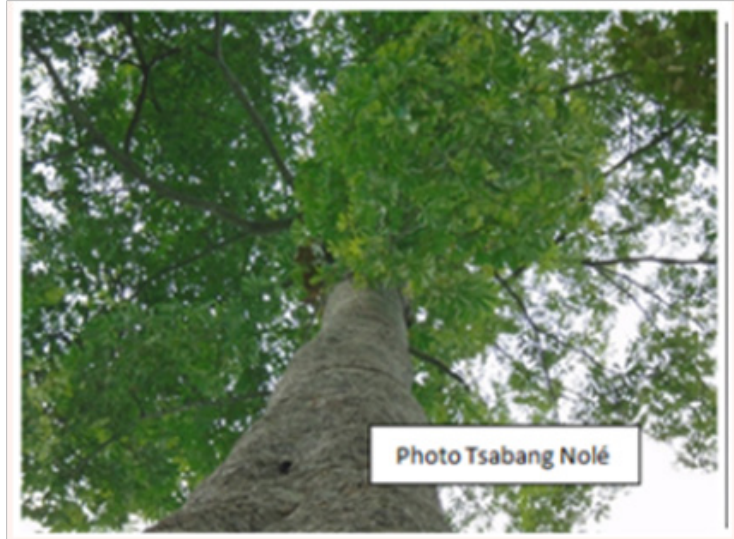

Supplementary Figure 4 Alstonia boonei tree.

\section{Conclusion}

Findings from this research indicated that the three plant species Alstonia boonei, Picralima nitida and Sarcocephaluslatifolius are good sources of medications and are commonly used by the local people to treat various diseases. However, because of their heavy exploitation for medicinal purposes, they are not commonly available in their natural habitats. Therefore the long term exploitation causes a real threat to the survival of these plant species. Hence, care must be taken to implement conservation strategies toward a good sustainable management of these natural resources. Further research on the isolation, identification, and commercialization of active ingredients from the crude extracts of these three plants will help reduce the demand and alleviate the ecological impact.

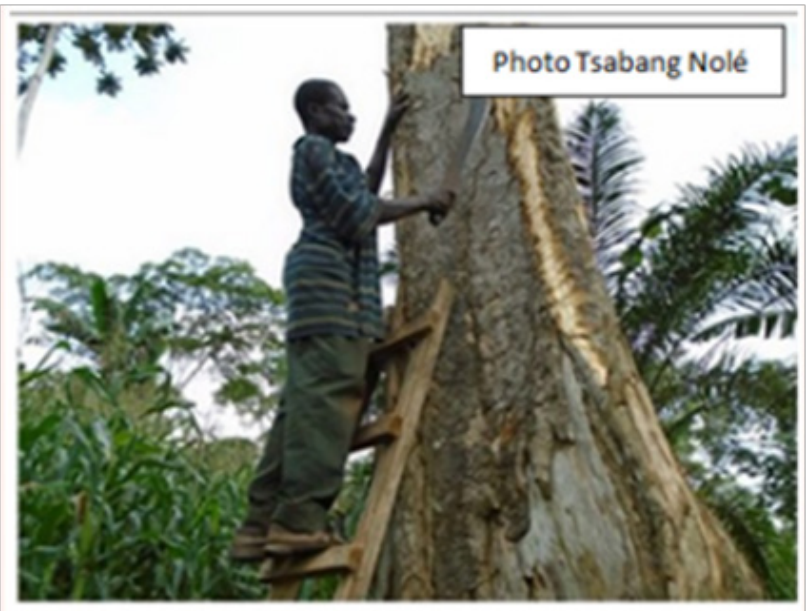

Supplementary Figure 5 No sustainable harvest of Alstonia boonei barks.

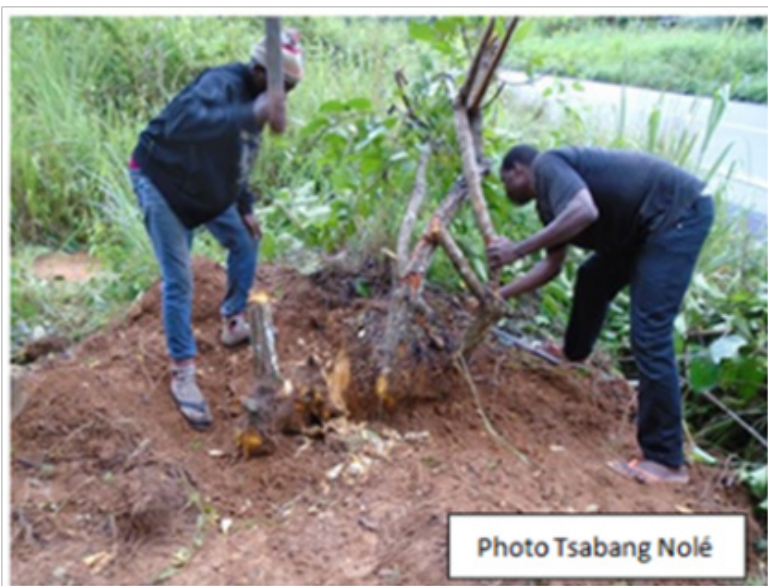

Supplementary Figure 6 No sustainable harvest of Sarcocephalium latifolius roots.

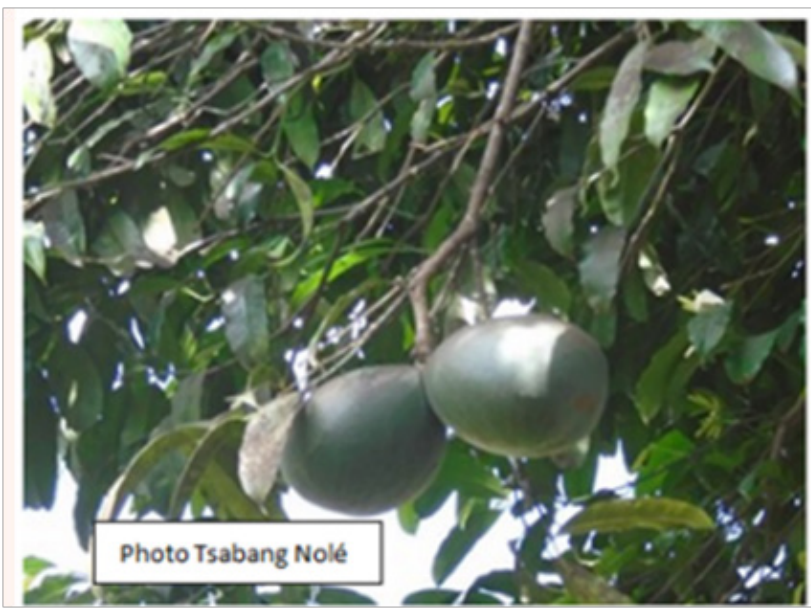

Supplementary Figure 7 Fruits of Picralima nitida. 


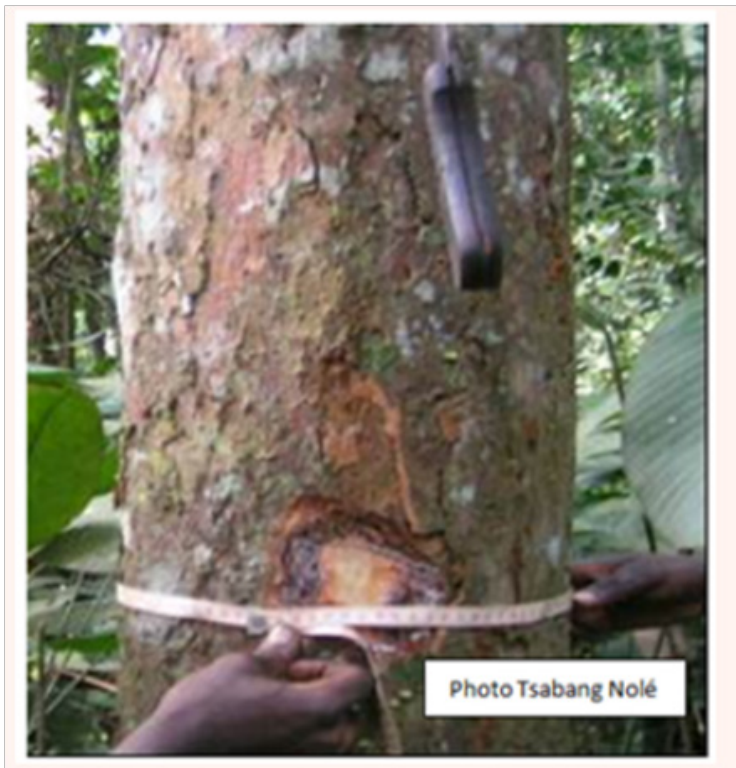

Supplementary Figure 8 Measurement of Coelocarium preussii (Myristicaceae)'scircumference at the breast high.

\section{Acknowledgements}

None.

\section{Conflicts of Interest}

The authors do not have any personal or financial interests.

\section{Funding}

None.

\section{References}

1. Opoku F, Akoto O. Antimicrobial and Phytochemical Properties of Alstonia boonei Extracts. Organic Chem Curr Res. 2015;4:1.

2. Kusari S, Tatsimo SJN, Zühlke S, et al. Tramadol- A True Natural Product? Angewandte Chemie International. 2014;53(45): 1207312076.

3. Randall I. Synthetic drug found in nature. Royal Society of Chemistry. 2013;p.19.
4. Boumendjel A, Sotoing Taïwe G, Ngo Bum E, et al. Occurrence of the synthetic analgesic tramadol in an African medicinal plant. Angewandte Chemie. 2013;52(45):11780-11784.

5. Tsabang N. Etude ethnobotanique des plants antidiabétiques et/ou antihypertensive du Cameroun. Thèse de Doctoral/Ph.D. Université de Yaouneé I, Cameroon, 2008. pp. 319.

6. Tsabang N, Lionel TDW, Nouboudem TA, et al. Ethnopharmacological surveys' methodologies for medicinal plants uses discovery and environmental threatens on recorded plants from indigenous knowledge in Cameroon. Global Journal of Medical Research. 2015;15(5).

7. Dallmeier F. Long-time monitoring of biology diversity in tropical forest areas, Methods for establishment and inventory for permanent plots. MAB disgest. 1992; p.1-73.

8. Sunderland TCH, Ros CI, Comiskey JA, et al. The vegetation of faunal reserve and Ejagham forest reserve, Cameroon. International Cooperative Biodiversity Group (ICBG). 1997; p. 345.

9. Peet RK. Plant community ecology: paper in honor of Robert $\mathrm{H}$. Whittaker. Advances in Vegetation Science, 1985; p. 185.

10. Braun BJ. Pflanzensoziologie, Springer, New York, USA,1964; pp. 845.

11. Greig Smith P. Quantitative plant ecology. (3rd edn), Butter-worths, Study in Ecology, London, USA, 1983;9:359.

12. Poissonnet J, Cesar J. Structure specific de la strate herbacée dans la savane à palmier de Lamto (Côte-d'Ivoire) Annis. Université Abidjan. 1972;1:577-601.

13. Afolabi CA, Ibukun EO, Emmanuel Afor, et al. Chemical constituents and antioxidant activity of Alstonia boonei; African Journal of Biotechnology. 2007;6(10):1197-1201.

14. Salome A, Chime EC, Ugwuoke V, et al. Formulation and Evaluation of Alstonia boonei Stem BarkPowder Tablets. Indian J Pharm Sci. 2013;75(2):226-230.

15. European Commission Directorate-General VIII Development and FAO. FAO, 1999;1-22.

16. Entraide Fibromyalgie Ouest. Une molécule antidouleur retrouvée à haute dose dans une plante, 2013;p. 5.

17. UICN. Catégories et critères de l'UICN pour la liste rouge. Commission de la sauvegarde des espèces de l'UICN, Gland, Suisse et Cambridge Royaume-Uni, USA, 2015; p. 32.

18. Diatta CD, Gueye M, Koma S, et al. Diversité de la flore et de la végétation ligneuses de la réserve de Ngazobil (Joal-Fadiouth) au Sénégal. Journal des Sciences. 2009;9(3): 1-13.

19. Plassart L. Sarcocephalium latifolius (Sm.) Université de Rouen UFER de Medecine et de Pharmacie, Germany, 2015; p. 142. 